\title{
Improving Human Resources Motivation In Tourism Entrepreneurship : A Review
}

\author{
Joko Setiyo $^{1 *}$, Heri Pratikto ${ }^{2}$, Sopiah $^{3}$ \\ ${ }^{1,2,3}$ Management Science Doctoral Program Students, Malang State University \\ ${ }^{*}$ Corresponding author: \\ Email: joko.setiyo.2004139@students.um.ac.id
}

\begin{abstract}
.
The review of this article will discuss how to increase the motivationof human resources in entrepreneurship in the tourism sector. Rural areas can benefit from the entrepreneurial dynamics created by small tourism businesses, especially when linked to the lifestyle of each entrepreneur. Several researchers regarding the contribution of small tourism businesses to improve the rural economy. The potential role of rural communities to increase tourism in rural areas should not be ignored. Related to increasing the motivation of human resources in entrepreneurship in the field of tourism. This study explores the motivations and management practices of tourism entrepreneurship as well as the consequences of community actions, considering the data obtained from several small tourism entrepreneurs, the efficiency and success of entrepreneurship.
\end{abstract}

Keywords: Motivation, HR, Entrepreneurship, Tourism.

\section{INTRODUCTION}

MSMEs in tourism face many obstacles in many cases exacerbated by their rural location and reduced size. In the context of dealing with realities where entrepreneurs have to overcome various difficulties in managing, and reducing and making their business viable, such as a lack of human resources, managerial skills, or the inability to hire qualified employees. are business activities carried out by individuals, households, or small business entities. Small and medium enterprises are an important part of the economy in providing employment in the private sector. The tourism industry is driven by entrepreneurs who are individuals who usually have vision, innovation and creativity (Carmichael \& Morrison, 2011).Such entrepreneurial behavior characteristics are critical to the performance of tourism enterprises (Getz \& Petersen, 2005), which are commonly referred to as productivity or competitiveness (Al-Najjar, 2014; Chen, 2014; Sainaghi et al., 2017), or a multidimensional approach to growth. companies such as market share and increased sales and profits (Sainaghi et al., 2017). Successful entrepreneurial behavior consists of the interaction of innovation, proactiveness, and risk taking as key elements that determine a firm's EO (Covin \& Slevin, 1989), and is linked to internal factors such as the firm's financial resources (Wiklund \& Shepherd, 1989).

2005) as well as external factors such as network and environmental dynamism conditions, all of which affect the performance of financial firms (Eggers et al., 2014; Narver et al., 2004). Existing research is widely agreed that environmental conditions are also very important to explain the development of entrepreneurship in the tourism industry (Carmichael \& Morrison, 2011; Köseoglu, Topaloglu, Parnell, $\&$ Lester, 2013). These circumstances range from a competitive environment and the extent of integration within a community or network (Beritelli, 2011) to human resources, politics, seasons, fluctuating 
demand and technological change (Atuahene-Gima, Slater, \& Olson, 2005; Morrison \& Teixeira, 2005). , 2004). Following previous research (e.g., Covin, Eggers, Kraus, Cheng, \& Chang, 2016; Eggers et al., 2013; Yusuf, 2002), This study adopts the view that financial networks and resources are highly relevant constructs with respect to EO as a potential driver of firm performance in a tourism industry setting, which is affected by the uncertainty of the environment in which each firm operates. In the following section, all factors both internal and external.Motivation, in this context, is often associated with the desire to improve the quality of life of entrepreneurs and their families, along with several intangible rewards such as pride, personal growth and a sense of accomplishment and empowerment (Lashley \& Rowson, 2010; Marcketti et al., 2006; Markantoni \& van Hoven, 2012). Increasingly ecological principles and sustainable values are additional motivations ('ecopreneurs'), while also the desire to "inform and educate" tourists about agriculture, countryside and their conservation (tourism) has been reported among rural tourism entrepreneurs (Boluk \& Mottiar, 2014; McGehee \& Kim, 2004).

Social entrepreneurs in tourism have been reported as individuals who identify, in arural context, opportunities to achieve their social goals while helping communities to maintain their way of life, either facilitating the development of a collective vision for destination development, or implementing responsible tourism initiatives (e.g. voluntary tourism). ) (Mottiar, Bolluk \& Kline, 2018). In social psychology, an individual who wants to become an entrepreneur is inspired by two factors: personality (Ilies \& Hakim, 2003) and adventurous environment (Ucbasaran et al., 2009; Unanue, Vignoles, Dittmar, \& Vansteenkiste, 2016). When this aligns during adventurous periods, entrepreneurial aspirations occur, prompting individuals to take entrepreneurial opportunities (Lee \& Venkataraman, 2006; Xie, Xie, \& Martínez-Climent, 2019). Entrepreneurial aspirations are caused by a mixed desire for greater economic, social, and psychological values that motivate entrepreneurs to pursue new ventures (Hessels, van Gelderen, \& Thurik, 2008). When the existing labor market is more promising or efficient than seeking to achieve these values, individuals prefer to remain employed.Conversely, when individuals can observe the possibility of realizing greater social, economic, and psychological values, they aspire to entrepreneurship.

Therefore, While aspirations drive entrepreneurial practice, aspirations can also be the result of an individual's self-evaluation to pursue entrepreneurial success. Entrepreneurial aspirations are beliefs at the individual level and consist of a mixed concept of an individual's value mindset, abilities, traits, experiences, and adventurous environment. This study identified several factors with significant mediating or moderating effects: assessment of work-entrepreneurial alternatives (Kim, Fouad, \& Lee, 2018), wellbeing (or suffering) at work (Creed, Hood, \& Hu, 2017; Shepley et al. , 2017), career- related self-efficacy (Rigotti, Korek, \& Otto, 2018), and self-definition (Ucbasaran et al., 2009). This study thus argues that entrepreneurial aspirations are the desired outcome of entrepreneurial independence.Effective motivation from the perspective of social cognitive psychology and self-fulfillment theory in the context of entrepreneurship. Finally, it addresses several entrepreneurial questions: How can a theoretical framework better explain entrepreneurial motivation and the concept of self-efficacy? How does the framework reflect the incentives and behavior of employers? Which measures can predict the commitment of entrepreneurs to economic and social development? How policy can offer solutions for social entrepreneurship management from this entrepreneurial motivation perspective.Many studies have explored the relationship between economic development and entrepreneurship (Acs, Autio, \& Szerb, 2014; Audretsch \& Keilbach, 2004; Van Stel et al., 2005; Wong et al., 2005; Galindo, Mendez, \& Alfaro, 2010).

Researchers investigating the relationship between entrepreneurship, institutions and economic development are increasingly turning to evolutionary economics, and the closely related areas of institutional economics, for theoretical frameworks. Institutional economics provides insight into how formal and informal institutions facilitate or constrain entrepreneurship (Aidis et al., 2008; Begley, Tan, 
\& Schoch, 2005; Salimath \& Cullen, 2010; Thornton, Ribeiro-Soriano, \& Urbano, 2011; Turró, Urbano, , \& Peris Ortiz, 2014; Urbano \& Alvarez, 2014; Van Stel, Storey, \& Thurik, 2007; Veciana \& Urbano, 2008). Institutions are defined as "human- designed collective actions, such as government strategies, plans, policies or laws, business or industry norms, social norms, cultural beliefs, or general patterns of consumer behavior" (McLennan, Ritchie, Ruhanen, \& Moyle, 2014,P. 107). The literature argues that institutions have an impact on growth, with institutions considered the main driving factor that determines growth (Acemoglu et al., 2005; Rodrik, Subramanian, \& Trebbi, 2004). Institutions canreduce uncertainty, provide incentives for production and facilitate economic growth (Bjornskov \& Foss, 2013).

Autio et al. (2014) argue that there is a need"for a more detailed evaluation of the effectiveness of policy instruments" (p. 1106). Mok (2005) argues that government can play an important role in facilitating and supporting entrepreneurship. Indeed, governments often seek to develop entrepreneurship education, reduce regulation, or implement targeted policies (eg for women, youth or disadvantaged groups) to promote entrepreneurship (Autio et al., 2014). Given the possible importance of government strategies, plans and regulations in influencing entrepreneurship and delivering economic growth, it is surprising how very limited research is in this area (Moyle, Moyle, Ruhanen, Bec, \& Weiler, 2018). The literature shows that institutional and policy contexts influence industry's ability to facilitate entrepreneurial ethos, such as cultural practices, social contexts, government leadership and place management (Hart, 2003; Hayton, George, \& Zahra, 2002; Uhlaner \& Thurik, 2007). Harper (2003) argues that entry decisions relate to individual skills and the national economic context. Holmes Jr, Zahra, Hoskisson, DeGhetto, and Sutton (2016) argue for the importance of technology policy in stimulating entrepreneurship. The entrepreneurial discourse is clearly visible in 165 (or 34\%) of the 481 tourism strategies.

Around $90 \%$ of tourism areas have tourism strategies and $70 \%$ of tourism areas have entrepreneurial strategies. in tourism strategy. Of the 165 strategies, 58\% mentioned 'new/emerging business', 53\% mentioned the keyword 'entrepreneur*', 14\% mentioned 'start-up' and 14\% mentioned 'incubat*'. Throughout the time series, the number of tourism strategies with entrepreneurial discourse remained stable without significant changes over time $(y=0.001 \times+0.372$; Pearson2 $(14,481)=20.14, p$ $=.126)$. Considering the policy level, $43 \%$ of local level tourism strategies have an entrepreneurial discourse, compared to $36 \%$ of tourism strategies at national level, $32 \%$ regional and $29 \%$ state level. The local level was significantly more likely than other policy level strategies to have a focus on entrepreneurship $(\chi 2(1,481)=5.55, \mathrm{p}=.018)$. Analysis of the entrepreneurship strategic discourse text using Leximancer revealed that national and state-level entrepreneurship strategic discourses were associated with entrepreneurship, planning, skills development, and indigenous integration, while local strategies were associated with economic andfuture development (Figure 1). 018).

Analysis of the entrepreneurship strategic discourse text using Leximancer revealed that national and state-level entrepreneurship strategic discourses were associated with entrepreneurship, planning, skills development, and indigenous integration, while local strategies were associated with economic and future development (Figure 1). 018). Analysis of the entrepreneurship strategic discourse text using Leximancer revealed that national and state- level entrepreneurship strategic discourses were associated with entrepreneurship, planning, skills development, and indigenous integration, while local strategies were associated with economic and future development (Figure 1). 


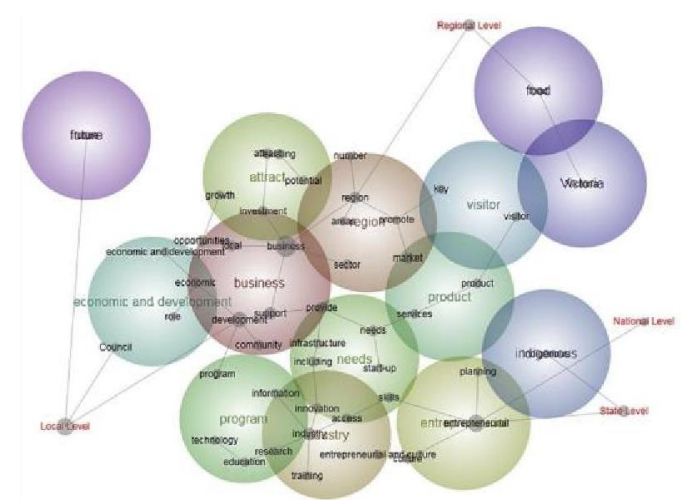

Fig 1. Strategic Tourism Entrepreneurship

Successful entrepreneurial behavior consists of the interaction of innovation, proactiveness, and risk taking as key elements that determine a company's EO (Covin \& Slevin, 1989), and is related to internal factors such as thecompany's financial resources (Wiklund \& Shepherd, 2005) as well as external factors such as network and environmental dynamism conditions, all of which affect the performance of financial firms (Eggers et al., 2014; Narver et al., 2004). Existing research is widely agreed that environmental conditions are also very important to explain the development of entrepreneurship in the tourism industry (Carmichael \& Morrison, 2011; Köseoglu, Topaloglu, Parnell, \& Lester, 2013). These circumstances range from a competitive environment and the extent of integration within a community or network (Beritelli, 2011) to human resources, politics, seasons, fluctuating demand and technological changes (Atuahene-Gima, Slater, \& Olson, 2005; Morrison \& Teixeira, 2004). Following previous research (e.g., Covin, Eggers, Kraus, Cheng, \& Chang, 2016; Eggers et al., 2013; Yusuf, 2002), this study adopts the view that financial networks and resources are highly relevant constructs with respect to EO as potential drivers of firm performance in tourism industry settings, which are affected by the uncertainty of the environment in which each each company operates. In the following section, all the factors both internal and external to the company considered in this study will beintroduced.

Economic, social, and physical changes in the STHF external environment can affect not only the business itself (Morrison, 1992) but also the image of the destination, which is highly valued by some business owners (Lai et al., 2017). Dedeke (2017) suggested that the success of sustainable tourism efforts in protected areas is associated with innovation and adaptability of the main actors. In addition, changes originating outside the destination's core tourism system can threaten the idealized representations ascribed to the area by owners and managers of small tourism enterprises, questioning these representations and encouraging thematization, which is critical to the destination's future image (Lai et al., 2017). The influence of these various dimensions of the external environment on the performance of small and medium-sized companies cannot be ignored. On the other hand, small companies need not behave only as recipients of environmental change; they can also actively work in and with the environment (Malecki and Tootle, 1996). Kelliher and Henderson (2006) developed a learning framework for small business environments that recognizes the learning impact of a small workforce, ownercentred culture, and simple organizational structure, and the specific time and resource constraints for small businesses.

Lai et al. (2017) used a social representation approach to determine how small tourism firms cope with non-tourism-induced change, and suggested that countermeasures are mobilized by perceived threats to destination representation and hampered by feelings of helplessness, uncertainty, and distrust of government and/or industry. In particular, unlike the case in developed countries, where small accommodation businesses are usually founded on a "lifestyle" motivation, small rural accommodation businesses in China are mostly profit-oriented businesses, and thus tend to expand their accommodation 
capacity in response to increasing demand for rural tourism (Ye et al., 2019). Ye et al.'s (2019). Research implies that business development and related commercialization can undermine the authenticity of the lifestyle and thus tend to expand their accommodation capacity in response to the increasing demand for rural tourism (Ye et al., 2019). Ye et al.'s (2019). Research implies that business development and related commercialization can undermine the authenticity of the lifestyle and thus tend to expand their accommodation capacity in response to the increasing demand for rural tourism (Ye et al., 2019). Ye et al.'s (2019). Research implies that business development and related commercialization can undermine the authenticity of the lifestyle countryside and the host-guest relationship. Today, the number of small accommodation businesses has increased dramatically in the era of the sharing economy, and the sharing economy ecosystem consists of four interrelated subsystems with diverse destination-seeking interest groups located at different layers (Leung et al., 2019).

Despite the challenges in achieving long-term goals, there are positive outcomes from the collective entrepreneurial process in the case of dispersed hotels. Knowledge has developed and accumulated during the process: "I have learned a lot about tourism, about architecture, about city development, I have learned a lot about volunteering" (interview, initiator). The qualities and potential of thecity have been highlighted, formulated and distributed among local residentsand politicians. Finally, social capital has developed which can support future hotel developments and lead to other local initiatives in the future. At Lildstrand the process has been transformative as it creates a feeling of empowerment in the community. They have moved from a situation of low optimism, believing that it is unlikely to change basic living conditions, towards achieving a stronger and more confident approach to community development, driven by the funding raised for the sub-projects and the perceived ability to navigate within the political environment. local. According to interviewees, development projects have changed social relations by increasing people's access to power and resources, and have made Lildstrand a more attractive place to live.

\section{PREVIOUS RESEARCH}

Previous research is a reference source used as a benchmark forresearchers to analyze a study.

Table 1. Previous Research

\begin{tabular}{|l|l|l|l|}
\hline No & $\begin{array}{c}\text { Writer's } \\
\text { name,Year }\end{array}$ & $\begin{array}{c}\text { Location } \\
\text { Study }\end{array}$ & \multicolumn{1}{c|}{ Findings and Results } \\
\hline 1. & $\begin{array}{l}\text { Conceicao } \\
\text { Cunha, } \\
2020\end{array}$ & Portugal & $\begin{array}{l}\text { Challenging findings about small businesses in tourism,Efficiency andsuccess } \\
\text { businessproven as a constant concern, and management practices, although informal, it's } \\
\text { proven }\end{array}$ \\
\hline & & $\begin{array}{l}\text { accurate. In fact, e speciallyentrepreneurs who are more driven by motivation } \\
\text { lifestyle show concernto continuity, reflected in cross-selling strategies, investment } \\
\text { in biological agriculture, environmentally friendly management, or diverse settings } \\
\text { into local cultural values. }\end{array}$ \\
\hline
\end{tabular}




\begin{tabular}{|c|c|c|c|}
\hline 2. & $\begin{array}{l}\text { Chester KM } \\
\text { To, } 2020\end{array}$ & Spanish & $\begin{array}{l}\text { This study models the entrepreneurial self-efficacy framework as a pathway } \\
\text { structure for expandideg standing each in the context of social entrepreneurship. } \\
\text { Empirical data support the correlationof situation-bound self- efficacy with } \\
\text { severalantecedent:masteryexperience entrepreneurship,autonomy entrepreneur } \\
\text { ship,firmnesssocial, and effective rewards. While significant and valid, effective } \\
\text { rewardsrank the lowest.Entrepreneurial self-efficacy can explain motivational } \\
\text { outcomes in three constructs: spnnpgg,le aspirations entrepreneurship,andwell- } \\
\text { beingeudaimonic. The factorial structure and causal pathways were evaluatedby } \\
\text { parametric SEM, providing evidence of variability in desired self-efficacy outcomes } \\
\text { accordingto entrepreneurs' self-attributes. The study recognizes that the survey should } \\
\text { be extended to more innovation and } \\
\text { entrepreneurship sectors. }\end{array}$ \\
\hline \multirow[t]{2}{*}{3.} & $\begin{array}{l}\text { Christian } \\
\text { Schott, } 2020\end{array}$ & $\begin{array}{l}\text { New } \\
\text { Zealand }\end{array}$ & $\begin{array}{l}\text { This study aims to critically examine the capacity of CBThomestays to } \\
\text { support progress on the } 2030 \text { Agenda with a particular focus on }\end{array}$ \\
\hline & & & $\begin{array}{l}\text { SDG1 No Poverty and SDG11 Sustainable Cities and Communities. Finding highlight } \\
\text { that many direct and indirect benefits created by CBT homestays. They not only help in } \\
\text { advance SDGs1 and 11, but broader benefits have also been identified that contribute to } \\
\text { advancing SDG3 Health and Welfare and Gender Equality SDG5. However,perspective } \\
\text { holistic which offered by SLF Scoones also uncovers some of the critical costs that risk } \\
\text { negating any progress towards SDGs } 1 \text { and } 11 \text { as it undermines people's important } \\
\text { natural and social capital. Therefore we need to realize that the net positive contribution } \\
\text { to SDGs from CBT homestays is not given,and that planning and management Careful } \\
\text { consultancy is essential in mitigating the negative impacts of this type of tourism } \\
\text { development. }\end{array}$ \\
\hline 4. & $\begin{array}{l}\text { Char-lee } \\
\text { Moyle, } 2020\end{array}$ & Australia & $\begin{array}{l}\text { Connection Among strategytourism entrepreneurship and growth tourist use panel } \\
\text { Region Australia and the policy level. There is Proof discourse entrepreneurship in } 165 \\
\text { (or } 34 \% \text { ) of the } 481 \text { strategies. Importantly for policy makers, the results show having a } \\
\text { tourism strategy leads to economic growth regardless of having a focus on } \\
\text { entrepreneurship. }\end{array}$ \\
\hline 5. & $\begin{array}{l}\text { Fleming } \\
\text { Sorensen, } \\
2021\end{array}$ & Denmark & $\begin{array}{l}\text { Small private actors in Mosen are similar to other small entrepreneurs identified in the } \\
\text { nature tourism research. They often lack a professional approach to the tourism } \\
\text { business and have limited tourism knowledge and, in many cases, limited general } \\
\text { business knowledge.Traditional business-oriented activities, including proper market } \\
\text { analysis and marketing, are rarely the focus, and there is no need to create a business } \\
\text { because you are an excellent } \\
\text { salesperson. }\end{array}$ \\
\hline 6. & $\begin{array}{l}\text { Andreas } \\
\text { Kalmuenzer, } \\
2019\end{array}$ & Taiwan & $\begin{array}{l}\text { Finding this causing a number of implication practical. First,important for } \\
\text { It is understood that there is more than one way for tourism entrepreneurs to achieve } \\
\text { higher performance. This study has provided six pathways that lead to higher tourism } \\
\text { enterprise performance. Second, resethairschimply that ideal company shouldknow the } \\
\text { environment their business and how to act in this environment, because need a } \\
\text { constellation of different factors to perform well. Tourism associations or local } \\
\text { policymakers can support owner managers in preparing for this endeavor by providing } \\
\text { tailor-made training. }\end{array}$ \\
\hline \multirow[t]{2}{*}{7.} & $\begin{array}{l}\text { Shawang, } \\
2018\end{array}$ & $\begin{array}{l}\text { hong } \\
\text { kong, } \\
\text { China }\end{array}$ & $\begin{array}{l}\text { This study investigates the entrepreneurial motivation of STHF operators from a } \\
\text { dynamic perspective and identifies fouprattern motivation: shift from lifestyle } \\
\text { orientation to }\end{array}$ \\
\hline & & & $\begin{array}{l}\text { orientation business; maintenance orientation lifestyle; shift from business orientation } \\
\text { to lifestyle orientation; and maintenance of business orientation. Using Bandura's } \\
\text { (1986) SCT approach, the study revealed different personal and environmental factors } \\
\text { that influence entrepreneurial motivation for each pattern.Based on SCT, this study } \\
\text { provides a comprehensive motivation model for entrepreneurship in sector tourism and } \\
\text { hospitality. }\end{array}$ \\
\hline 8. & $\begin{array}{l}\text { Matthias } \\
\text { Thuen } \\
\text { Jorgensen, } \\
2021 \\
\end{array}$ & Denmark & $\begin{array}{l}\text { In connection Among tourist,entrepreneurship social and development Public,we have } \\
\text { investigate how the principles of entrepreneurship social (tourist) used by Public local } \\
\text { for fight depopulation and setbacks in the two goals of Denmark, as well as the } \\
\text { characteristics of this social type. Entrepreneurial process. Weargues that a more }\end{array}$ \\
\hline
\end{tabular}




\begin{tabular}{|l|l|l|}
\hline & $\begin{array}{l}\text { lollective perspective on social entrepreneurship in the tourism context is needed an } \\
\text { define EntrepreneurshipSocial Collective Tourism as: the process of using tourism } \\
\text { activities as a means for collaborative social problem solving between the same } \\
\text { and diverse actors. }\end{array}$ \\
\hline
\end{tabular}

\section{CONCLUSION}

Thus, the review shows that Improving Human Resource Motivation in Tourism Entrepreneurship contributes to increasing HR. In addition, this review highlights the characteristics of entrepreneurship, not only through the creation of successful businesses in rural areas, but also by promoting networks that contribute to the welfare of local communities in tourist areas.

In rural areas entrepreneurship is promoted by entrepreneurs in specific ways to manage businesses in line with what is sometimes considered to be the essence of tourism in rural areas. The framework model used by entrepreneurship is self-efficacy as a pathway structure to expand understanding of each in the context of entrepreneurship in a social form.Entrepreneurial self-efficacy can explain the results of motivation in construction, namely the struggle for goals, entrepreneurial aspirations, and welfare. Current entrepreneurial observations are mostly related to government funded projects with strong social mission innovation initiatives.

\section{REFERENCES}

[1] Acs, ZJ, Stam, E., Audretsch, DB, \& O'Connor, A. (2017). Line of descent trepreneurial ecosystem approach. Small Business Economics, 49(1), https://doi.org/10.1007/s11187-017-9864-8.

[2] Akbaba, A. (2012). Understanding small tourism businesses: A perspective from Turkey.

Journal of Hospitality and Tourism Management, 19, 1-17.

[3] Ashworth, G., \& Voogdt, H. (1991). Can the place be sold for tourism?In G. Ashworth, \& B. Congratulations (Eds.). Marketing of tourist attractions (pp. 1-16). London and New York: Routledge. Ateljevic,J. (2007). Small tourism companies and management practices in New Zealand: The mid-stage macro area. Tourism Management, 28, 307-316.

[4] Ateljevic, I., \& Doorne, S. (2000). Stay inin the fence: Entrepreneurial lifestyle in tourism. Journal of SustainableTourism, 8(5), 378-392.

[5] Aarstad, J., Haugland, SA, \& Greve, A. (2010). Performance spillover effect on the networktrepreneurial: Assessing the dyadic theory of social capital. Entrepreneurial Theoryand Practice, 34(5), 1003-1020.

[6] Asante, EA, \& Affum-Osei, E. (2019). Entrepreneurship as a career option:The impact of locus of control on the recognition of potential entrepreneurs' opportunities.Journal of Business Research, 98, 227-235.

[7] Austin, J., Stevenson, H., \& Wei-Skillern, J. (2006). Social environment and commercial trepreneurship: Same, different, or both? Entrepreneurship: Theory and Practice,30,1-22.

[8] Bacq, S., \& Alt, E. (2018). Feeling capable and valued: A prosocial perspective onlink between empathy and social entrepreneurial intention. Journal of Business Adventure, 33(3), 333-350.

[9] Bandura, A. (1991). Social cognitive theory of self-regulation. Organizational Behavior and The Human Decision Process, 50, 248-287.

[10] Bandura, A. (2012). On the functional properties of perceived self-efficacy are reviewed return. Journal of Management, 38, 9-44.

[11] Barakat, S., Boddington, M., \& Vyakarnam, S. (2014). Measuring entrepreneurshipindependent efficacy to understand the impact of creative activities for learning innovation.

[12] Acharya, BP, \& Halpenny, EA (2013). Homestay as an alternative tourism product for sustainable community development: A case study of women-run tourism products in rural Nepal. Tourism Planning \& Development, 10(4), 367387.

[13] Anand, A., Chandan, P., \& Singh, RB (2012). Homestay in Korzok: Complementing rural livelihoods and supporting green tourism in the Indian Himalayas.Mountain Research and Development, 32(2), 126-136.

[14] Ashley, C. (2000). Impact of tourism on rural livelihoods: Namibian experience. London: Overseas Development Institute.

[15] Ball, J. (2004). As if knowledge and indigenous communities mattered: Transformative education in Canada's first state community. American Indian Quarterly, 28(3/4), 454-479. 
[16] BDICT. (2019).Report of tourist statistics of Bolikhamxay Province (Department Bolikhamxay Cultural and Tourism Information).

[17] Benur, AM, \& Bramwell, B. (2015). Development of tourism products and productsdestination diversification. Tourism Management, 50, 213-224. Bhalla, P.,

[18] Galindo, MA, Mendez, MT, \& Alfaro, JL (2010). Entrepreneurship, difference income distribution and economic growth. International Journal ofEntrepreneurial Management, 6, 131-141.

[19] Gomezelj, DO (2016). A systematic review of research on innovation in

[20] hospitality and tourism. International Journal of Contemporary Hospitality Management. On line. 28(3), 516-558.

[21] Andersen, B., \& Fagerhaug, T. (2006). Root cause analysis: Tools and techniques simplified. Quality Press.

[22] Andriotis, K. (2018). Degrowth in tourism: Conceptual, theoretical and problems philosophical. International CABI.

[23] Ateljevic, I., \& Doorne, S. (2000). 'Stay on the fence': Entrepreneurship style living in tourism? Journal of Sustainable Tourism, 8(5), 378-392. https://doi.org/10. 1080/0966958008667374.

[24] Bærenholdt, JO, \& Grindsted, TS (2021). Mobilization for the market city hotel that Scattered: Tourist site management project to reuse empty shops. In C. Lassen, LH Laursen, \& GR Larsen (Eds.), Mobility and place management. Routledge. https://doi.org/10.1080/02642060903580649.

[25] Benz, M. (2009). Entrepreneurship is a non-profit activity. International Journal of Entrepreneurship and Management, 5(1), 23-44.

[26] Buckley, R. (2012). Sustainable tourism: Research and reality.History Tourism Research, 39(2),528-546. https://doi.org/10.1016/j.annals.2012.02.003.

[27] Cosme, I., Santos, R., \& O'Neill, DW (2017). Assessing degrowth discourse: A review and analysis of academic degrowth policy proposals.Production Cleaning Journal, 149, https://doi.org/10.1016/j.jclepro.2017.02.016.

[28] Crnogaj, K., Rebernik, M., Hojnik, BB, \& Gomezelj, DO (2014). Build research models of sustainable entrepreneurship in the tourism sector.Kybernetes, 43(3), 377-393. https://doi.org/10.1108/K-07-2013-0155.

[29] Ahmad, SZ (2015). Entrepreneurship in the small and medium-sized hospitality sector. Issue Recent in Tourism, 18(4), 328-349. https://doi.org/ 10.1080/13683500.2014. 934211.

[30] Al-Najjar, B. (2014). Corporate governance, tourism growth and performance companies: Evidence from publicly listed tourism companies in five Middle Eastern countries. Tourism Management, 42, 342-351. https://doi.org/10.1016/j.tourman.2013.09.008.

[31] Armstrong, JS, \& Overton, TS (1977). Estimating nonresponse bias in mail survey. Journal of Marketing Research, 14(3), 396-402. https://doi.org/10.2307/3150783.

[32] Ateljevic, I., \& Doorne, S. (2000). Stay on the fence': Lifestyle entrepreneurship in tourism. Journal of Sustainable Tourism, 8(5), 378-392. https://doi.org/ 10.1080/ 0966958008667374.

[33] Atuahene-Gima, K., Slater, SF, \& Olson, EM (2005). Contingent value of

[34] responsive and proactive market reorientation for new product programperformance. Journal of Product Innovation Management, 22(6), 464-482.https://doi.org/10.1111/j.1540-5885.2005.00144.x.

[35] Ahmad, SZ, Jabeen, F., Khan, M., 2014. Entrepreneur's choice in business ventures: Motivation for choosing a home-stay accommodation business in Peninsular Malaysia. int. J. Hospital. Manage. 36, 31-40.

[36] Altinay, L., Madanoglu, M., Daniele, R., Lashley, C., 2012. Effects of Tra and Traits psychological characteristics of entrepreneurial intentions. int. J. Hospital. Manage. 31, 489-499.

[37] Altinay, L., Saunders, MNK, Wang, CL, 2014. The influence of culture on judgment trust in customer relationship development by ethnic minority small businesses. J. Small Bus. Manage. 52(1), 59-78.

[38] Andriotis, K., 2002. The scale of hospitality companies and local economic development- evidence from Crete. Tour. Manage. 23, 333-341.

[39] Ateljevic, I., Doorne, S., 2000. 'Staying on the fence': lifestyle entrepreneurship in tourism. J. Defend. Tour. 8 (5), 378-392.

[40] Biddulph, R. (2018). Social entrepreneurship and inclusive tourism. Five cases in Siem Reap, Cambodia. Geography of Tourism, 20(4), 610-629. https://doi.org/10.1080/ 14616688.2017.1417471.

[41] Buzinde, C., Shockley, G., Andereck, K., Dee, E., \& Frank, P. (2017). Theorizesocial entrepreneurship in tourism studies. In PJ Sheldon, \& R. Daniele (Eds.), Social entrepreneurship and tourism: Philosophy and practice. Jumper.

[42] Carstensen, MB (2011). The man vs. paradigm the bricoleur: Bricolage as alternative visions of agency in ideational change. European Political Science Review, 3(1), $147-167$. https://doi.org/10.1017/S1755773910000342.

[43] Chamberlin, N. (1977). Rebuilding American values. Basic Book. 
[44] Dacin, MT, Dacin, PA, \& Tracey, P. (2011). Social entrepreneurship: A critique and future direction. Organizational Science, 22, 1203-1213.https://doi.org/10.1287/orsc.1100.0620.

[45] Dahles, H., Khieng, S., Verver, M., \& Manders, I. (2019). Social entrepreneurship and tourism in Cambodia: Promoting community engagement. Journal of Sustainable Tourism, 28(6), 816-833. https://doi.org/ 10.1080/09669582.2019.1706544.

[46] Hari, J., \& Mody, M. (2017). Typology of social entrepreneurship and tourism: Conceptual framework. In PJ Sheldon, \& R. Daniele (Eds.), Social entrepreneurship and tourism: Philosophy and practice. Jumper. Dees,

[47] G. (1998). Definition of social entrepreneurship. Kauffman and Foundation Stanford University.

[48] Dees, G., \& Anderson, BB (2003). Profit-seeking social enterprise. In M. Kourilsky, \& W. Walstad (Eds.), Social Entrepreneurship (pp. 1-26). Senate Hall Academic Publishing.

[49] Defourny, J. (2001). From the third sector to social enterprises. In C. Borzaga, \& J. Defourny (Eds.), The emergence of social enterprises (pp. 1-18).

[50] Routledge. Defourny, J., \& Nyssens, M. (2006). Defines a social enterprise. In M. Nyssens (Ed.), Social enterprise: At the intersection ofmarkets, public policy and civil society (pp. 3-26). Routledge. 